\title{
Meningoencephalitis by Naegleria fowleri. Epidemiological study in Anzoategui State, Venezuela
}

\author{
Meningoencefalite por Naegleria fowleri. Estudo epidemiológico \\ no Estado de Anzoategui, Venezuela
}

\author{
Julman R. Cermeñoㅁ, Isabel Hernández ${ }^{1}$, Helal El Yasin², Rubén Tinedo², Raúl Sánchez ${ }^{3}$, \\ Gladys Pérez ${ }^{4}$, Rosalía Gravano ${ }^{1}$ and Aida Ruiz ${ }^{1}$
}

\begin{abstract}
A case of primary amoebic meningoencephalitis produced by Naegleria fowleri was diagnosed in the Independencia county of Anzoategui State, Venezuela. This case motivated the realization of the present epidemiological study with the aim of identifying free-living amoebae in this area. Representative water samples were taken and physicochemical and microbiologic analyses were carried out. Trophozoites and cysts of Naegleria spp, were detected in $44.4 \%(n=4)$. An excellent concordance was found among the observations of free-living amoebae in smears and those of monoxenic cultures in non nourishing agar with Klebsiella pneumoniae (Kappa=1; $p=0.003$ ). A variable load of aerobic mesophils was obtained. Moulds and yeast averages presented $3.0 \mathrm{CFU} / \mathrm{ml}\left(S D_{ \pm} 2.0\right)$ and $102.9 \mathrm{CFU} / \mathrm{ml}\left(S D_{ \pm} 32.2\right)$, respectively. One hundred per cent of the samples presented a most probable number of total and fecal coliforms of 240,000 NMP/100mL. Naegleria spp was present in waters of the Independence county of Anzoategui State, which constitutes a risk for people that use these sources.
\end{abstract}

Key-works: Amoebic meningoencephalitis. Epidemiology. Free-living amoebae. Naegleria fowleri.

\section{RESUMO}

Um caso de meningoencefalite amebiana primária, causada por Naegleria fowleri, foi diagnosticada no município de Independência no Estado de Anzoategui, Venezuela. Este caso motivou a realização deste estudo epidemiológico com o objetivo de identificar amebas de vida livre nessa área. Foram colhidas amostras representativas de água e realizadas análises fisicoquímicas e microbiológicas. Trofozoítos e cistos de Naegleria spp foram detectados em 44,4\% (n=4). Verificou-se excelente concordância entre a observação das amebas de vida livre em esfregaços e aquelas de culturas monoxênicas em ágar não nutriente com Klebsiella pneumoniae (Kappa=1; $p=0,003$ ). Obteve-se uma carga variável de microrganismos mesófilos aeróbicos. As médias de mofos e leveduras foram de 3,0 CFU/ml $(S D+2,0)$ e 102,9 CFU/ml(SD+32,2), respectivamente. Cem por cento das amostras apresentaram um número maior provável de coliformes totais e fecais de $240.000 \mathrm{NMP} / 100 \mathrm{ml}$. Naegleria spp estava presente nas águas do município de Independência no Estado de Anzoategui, o que constitui um risco para a população que usa essas fontes.

Palavras-chaves: Meningoencefalite amebiana. Epidemiologia. Amebas de vida livre. Naegleria fowleri.

Free living amoebae (FLA) can be acquired by contact, inhalation or aspiration of contaminated water. In the last four decades, about 200 cases of systemic infections by Acanthamoeba have been reported, more than 100 cases of Ballamuthia mandrillaris and 200 cases of meningoencephalitis by Naegleria fowleri ${ }^{131517}$. The number of infections caused by these protozoa will probably increase ${ }^{613}$.
This is a group of aerobic, amphizoic protozoa with a cosmopolitan distribution that are included in the following genera: Naegleria, Acanthamoeba, Balamuthia and Sappinia ${ }^{17}$. Trophozoites live in natural fresh water; they grow in great numbers and phagocyte bacteria, fungus and organic matter. They have also been isolated from the air, possibly contaminated by dust suspension?

\footnotetext{
1. Departamento de Parasitología y Microbiología, Escuela de Medicina, Universidad de Oriente, Núcleo Bolívar. Venezuela. 2. Hospital General "Luis Felipe Guevara Rojas”, El Tigre. Edo. Anzoátegui. Venezuela. 3. Unidad de Diagnóstico Médico Especializado (UDIMES), Ciudad Bolívar, Estado, Bolívar, Venezuela. 4. Unidad de Diagnóstico Biomédico Bolívar (UNDIBIBO), Ciudad Bolívar, Estado, Bolívar, Venezuela.

Address to: Dra. Julman Cermeño. Avenida 17 de Diciembre. Centro Comercial Country. Local $3^{\circ}$ Piso 1. Ciudad Bolívar, Estado Bolívar, 8001, Venezuela.

Telefax: + $5802856543291 ; 616923$

e-mail: jcerme@cantv.net; spenna@cantv.net

Recebido para publicação em 20/5/2005

Aceito em 31/3/2006
} 
Among the pathogenic species of the genus Naegleria, only $N$. fowleri is considered pathogenic for humans, while species like $N$. australiensis, $N$. philipinensis and $N$. italica can be pathogenic for experimental animals. A. cultbersoni, A. castellani, $A$. hatchetti and A. polyphaga are pathogenic species for humans. The genus Ballamuthia includes B. Mandrillaris and Sappina diploidea is the only pathogenic species of this genus ${ }^{2489131517}$.

Primary amoebic meningoencephalitis (PAM) caused by $N$. fowleri is an acute, suppurating infection of the brain and meninges. It is usually observed in otherwise healthy non immunocompromised children and teenagers, with a history of swimming in acclimated pools, ponds, lakes, brooks and channels with untreated water, often in the summer months ${ }^{2415}$. Jumping and diving are risk factors because they may cause direct trauma to the nasal mucosa allowing for invasion by these amoebae ${ }^{513}$. This disease shows bad prognosis in humans; the time between contact with the amoebae and the onset of symptoms may vary from 2 to 15 days. Thoracic pain, headache, lethargy and alteration of sense of smell are early symptoms. Progressive symptoms like fever, vomiting, neck rigidity, mental confusion and lung edema may occur, usually 3 to 5 days before death. Amoeba invasion causes ulcers in the nasal pharyngeal mucosa and neuritis and necrosis of the olfactory nerves. PAM can be misdiagnosed as acute suppurating bacterial meningitis. The cause of death is often respiratory arrest ${ }^{4}$. PAM diagnosis is realized by determining the presence of amoebae in the cerebrospinal fluid (CSF), by biopsy or culture in non nourishing agar enriched with bacteria. Furthermore, the amoebae can be identified using indirect immunofluorescence or immunoperoxidase techniques and molecular biology ${ }^{6} 18$.

The aim of this study was to report the first case of PAM by $N$. fowleri in the "Hospital Luis Felipe Guevara" from El Tigre City (Anzoategui State, Venezuela) and to show the presence of free-living amoebae (FLA) that are potentially pathogenic in untreated water in Independencia county where the present case came from.

\section{MATERIAL AND METHODS}

The first case of PAM in the Emergency Ward of "Hospital Luis Felipe Guevara Rojas" in El Tigre City is described and a descriptive transverse study was carried out, in order to identify FLA that are potentially pathogenic in untreated water coming from natural sources in Independencia county, Anzoátegui State. Thus, untreated water samples were taken from rivers and brooks in the area of this county. There are 7 rivers and 13 brooks in the cited area, of which 1 river and 8 brooks were selected for sample retrieval. These were La Peña river and the following brooks: El Piñal, Calambra, Puente Castillo1, Puente Castillo 2, Morichal del Medio, Puente Santojo, Carmona and San Antoñico.

Ten samples of water were collected in each place, using sterile tubes, giving a total of 90 samples. A smear was performed and stained using Giemsa and ferric hematoxylin for direct observation of the amoebae, as well as morphometric measurements. The water was centrifuged and 10 drops of sediment were placed on a glass lamina and allowed to dry at room temperature for 24 hours.

For the microbiological study, water samples were collected using $300-500 \mathrm{ml}$ glass bottles sterilized at $121^{\circ} \mathrm{C}$ for 15 minutes and protected with sterile paper around the neck of the bottle. The water samples were collected without using any type of pump, following the rules of Normas de la Comisión Venezolana de Normas Industriales (COVENIN) of Ministerio de Fomento and physical, chemical, parasitological and microbiological analyses of the water were performed ${ }^{1112}$. Cultures were realized in monoxenic media with non nourishing agar containing Klebsiella pneumoniae, in duplicate ${ }^{6}$. Samples were taken from the cultures and special preparations were performed on slides in order to identify FLA and take morphometric measurements. When amoeba growth was detected, an experimental induction of the flagelliform protozoa was carried out by means of sterile distilled water in the medium.

The processing of all samples was realized in the Department of Parasitology and Microbiology, School of Medicine, Universidad de Oriente, Núcleo Bolívar, Ciudad Bolívar, Venezuela. Control samples of FLA were used with hematoxylineosin, trichromic, ferric hematoxylin and Giemsa stains.

Statistical analysis. The descriptive statistic $X^{2}$ test was used for analysis of the qualitative variables. Concordance between observations of the FLA in smears and cultures was determined using the Kappa index, which is a concordance between two different tests applied to a single population. The SPSS/PC statistical package for Windows, version 6.1, 1995 was used for this purpose.

\section{RESULTS}

Clinical case. A female child, aged 8 years old, living on a farm in a rural area (Fundo Palma Sola, vía La Peña) in Anzoátegui State, Venezuela, presented the following symptoms: frontal headache, vomiting and fever for 2 days prior to examination. Antecedents: BCG vaccination and frequent swimming in nearby brooks six days before the onset of symptoms. The physical exam revealed: bad general health; $\mathrm{BP}=100 / 70 \mathrm{mmHg}$; heart rate $110 \mathrm{~b} / \mathrm{min}$; respiratory frequency $25 \mathrm{rpm}$; temperature (axilla) $37.5^{\circ} \mathrm{C}$; paleness of skin and mucosas; drowsiness and restlessness; body weight $20.5 \mathrm{~kg}$; congestive oropharyngeal mucosa without lesions; isochoric pupils with slow response to light; neck rigidity; positive Brudzinki sign, hyperreflexia, Glasgow 12/15 and pain in the bladder area. Other data related to the physical exam was within normal limits.

Laboratory analysis showed the following: glycemia, $195 \mathrm{mg} / \mathrm{dl}$; urea, 30mg/dl; creatinine, 3.2mg/dl; $\mathrm{Na}+, 134 \mathrm{mEq} /$; $\mathrm{K}+, 3.2 \mathrm{mEq} / \mathrm{l} ; \mathrm{Ca}++, 7.6 \mathrm{mg} / \mathrm{dl}$; leukocytes, 21,200 $\mathrm{mm}^{3}$; polymorphonuclear, $76 \%$; lymphocytes, $24 \%$; hemoglobin, $12.3 \mathrm{~g} / \mathrm{dl}$; hematocrit, $38 \%$; platelets, $231,000 \mathrm{~mm}^{3}$; prothrombin, $14.5 \mathrm{sec}$; prothrombin time, $28 \mathrm{sec}$; alkaline phosphatase, 143UI/; alanine aminotransferase, 25UI/1; aspartate aminotransferase, 
12UI/l; total bilirubin, $0.93 \mathrm{mg} / \mathrm{dl}$; direct bilirubin, $0.09 \mathrm{mg} / \mathrm{dl}$; indirect bilirubin, $0.84 \mathrm{mg} / \mathrm{dl}$.

Analysis of the cerebrospinal fluid (CSF) showed xanthochromia and slight turbidity; alkaline reaction, $\mathrm{pH} 8$; Pandy positive, 130 cells $\mathrm{mm}^{3}, 10-12$ red blood cells per field; glucose, $38 \mathrm{mg} / \mathrm{dl}$; protein, $56 \mathrm{mg} / \mathrm{dl}$; direct microscopic exam showed amoeba trophozoites of around 6-8 per field (40X), polymorphonuclear 5-35 per field. Neither bacteria nor yeasts were observed. China ink and Ziehl-Neelsen were negative. Cultures for bacteria, mycobacteria and fungus were all negative. Monoxenic cultures for amoebae from samples of CSF realized in non nourishing agar with $K$. pneumonia showed amoeba growth at 24 and 48 hours.

Therapy using amphotericin B $0.8 \mathrm{mg} / \mathrm{kg} /$ day IV, rifampicin $20 \mathrm{mg} / \mathrm{kg} /$ day PO and dexamethasone $0.6 \mathrm{mg} / \mathrm{kg} / \mathrm{day}$ IV was given. Progressive hemodynamic and neurological deterioration was observed and the patient died 24 hours after she was admitted to hospital.

The macroscopic findings of necropsy were severe brain edema (weight: $1.300 \mathrm{~g}$ ) with compressive sulcus in the cerebellar amygdala, diffuse opacity of leptomeninges, bilateral edema and congestion of the lungs, pericardial effusion, hemorrhage of about $50 \mathrm{ml}$ in stomach and superficial hemorrhagic erosive gastritis.

Histologic studies, using hematoxylin-eosin stain, of the brain, cerebellum and bulb showed acute hemorrhagic fibrinleukocytary exudates in the subarachnoid spaces, which were greater in cerebellum. In the inflammatory exudate round structures of $15 \mu$ diameter were observed, in different states of viability and their morphology was compatible with $N$. fowleri (Figure 1). In the nervous tissue below the choroid inflammation of Virchow-Robin spaces, wide and edematous tissue was observed with $N$. fowleri trophozoites, both isolated and in conglomerates, invading the surrounding neutrophil. In these areas, there was evidence of inflammatory infiltrate of variable density, particularly in zones of tissular necrosis, together with vascular damage and hemorrhage, mainly in the cerebellum (Figure 2) at the level of Purkinje cells and the layer of granulose cells. A white substance showed a mild

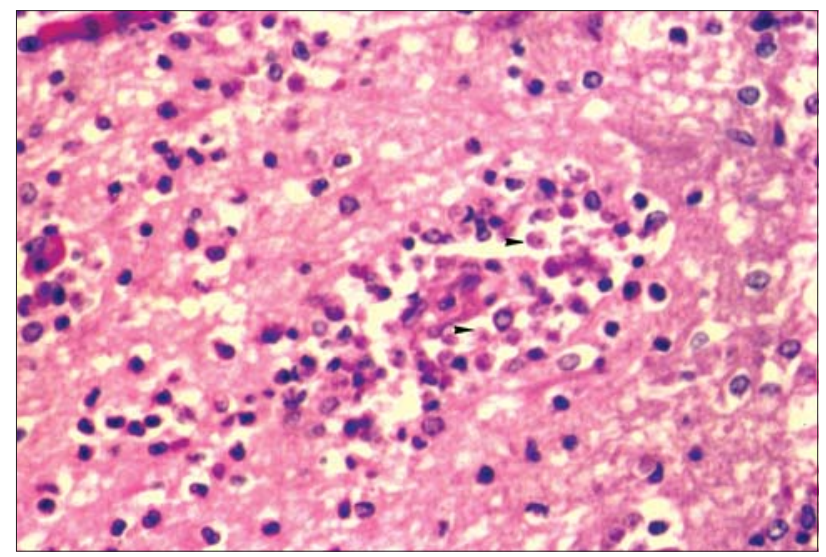

Figure 1 - Inflammatory exudates were observed showing round structures of $15 \mu$ diameter, in different states of viability and their morphology was compatible with $\mathrm{N}$. fowleri.

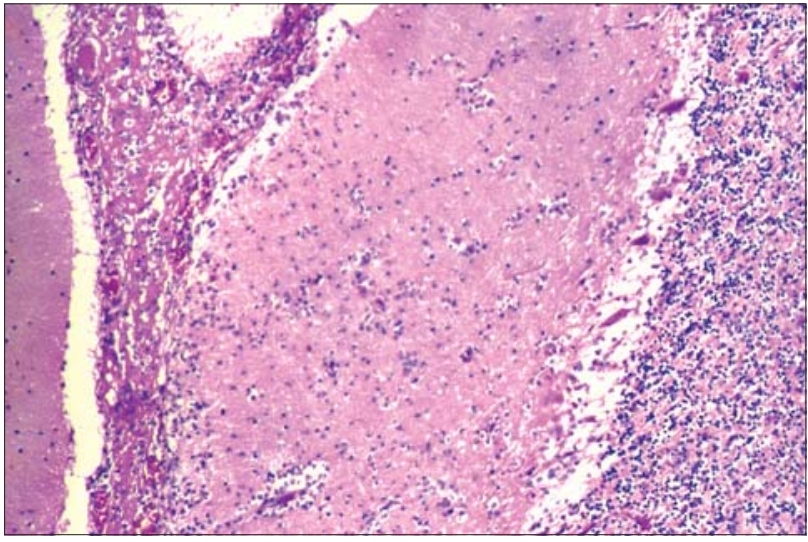

Figure 2 - Cerebellum evidence of inflammatory infiltrate of variable density particularly in zones of tissular necrosis, together with vascular damage and hemorrhage.

inflammatory compromise and edema. In the bulb, similar changes like those described in the cerebellum and inflammation of the choroid plexus were observed. A diagnosis of acute necrotizing hemorrhagic meningoencephalitis caused by N. fowleri was made.

Physicochemical, parasitological and microbiological analyses of water from Independencia County. There was evidence of trophozoites and cysts compatible with FLA of the genus Naegleria spp in $44.4 \%(n=4)$ of the samples and a great deal of bacteria and the absence of any other parasite was also detected. Trophozoites changed to flagellate form after 2 hours in sterile distilled water at $30^{\circ} \mathrm{C}$.

Table 1 shows the brooks where FLA were detected. Concordance between the observation of FLA in smears and in monoxenic cultures was excellent; Kappa $=1, \mathrm{ES}=0, X^{2}$ 9,000, d.f. $1, \mathrm{p}=0.003$.

Data concerning the physicochemical analysis of the water are shown in Table 2 . $\mathrm{pH}$ was $4.8(\mathrm{SD} \pm 0.4)$ in a range from 4.0 to 5.0. Water temperature when the samples were collected was $27.9^{\circ} \mathrm{C}( \pm 2.2)$, ranging from $23^{\circ} \mathrm{C}$ to $30^{\circ} \mathrm{C}$. The relationship between the presence of FLA and physicochemical characteristics of the water was not statistically significant.

Table 1 - Naegleria spp in cultures and smears of untreated Water in Independencia Country, Anzoátegui State, Venezuela.

\begin{tabular}{|c|c|c|c|c|c|c|c|c|}
\hline \multirow[b]{3}{*}{ Locality } & \multicolumn{4}{|c|}{ Smears } & \multicolumn{4}{|c|}{ Culture } \\
\hline & \multicolumn{2}{|c|}{ positive } & \multicolumn{2}{|c|}{ negative } & \multicolumn{2}{|c|}{ positive } & \multicolumn{2}{|c|}{ negative } \\
\hline & $\mathrm{n}^{\underline{0}}$ & $\%$ & $\mathrm{n}^{\underline{0}}$ & $\%$ & $\mathrm{n}^{\mathrm{o}}$ & $\%$ & $\mathrm{n}^{\underline{0}}$ & $\%$ \\
\hline \multicolumn{9}{|l|}{ Río } \\
\hline La Peña & & & 1 & & & & 1 & \\
\hline \multicolumn{9}{|l|}{ Riachuelos } \\
\hline El Piñal & & & 1 & & & & 1 & \\
\hline Calambra & & & 1 & & & & 1 & \\
\hline Puente Castillito. 2 & & & 1 & & & & 1 & \\
\hline Puente Castillito 1 & 1 & & & & 1 & & & \\
\hline Morichal del Medio & 1 & & & & 1 & & & \\
\hline Puente Santojo & 1 & & & & 1 & & & \\
\hline Carmona & & & 1 & & & & 1 & \\
\hline San Antoñico. & 1 & & & & 1 & & & \\
\hline Total & 4 & 4.4 & 5 & 55.5 & 4 & 44.4 & 5 & 55.5 \\
\hline
\end{tabular}


Table 2 - Electrolyte concentration and Load of microorganisms in water from Independence County.

\begin{tabular}{|c|c|c|}
\hline Electrolyte (Mq/1) & Mean \pm SD & Range \\
\hline $\mathrm{Cl}-$ & $14.0 \pm 1.1$ & $11.7 \pm 15.5$ \\
\hline $\mathrm{Na}+$ & $9.7 \pm 1.0$ & $8.2 \pm 11.2$ \\
\hline $\mathrm{K}+$ & $0.5 \pm 7.2$ & $0.4 \pm 0.6$ \\
\hline \multicolumn{3}{|c|}{ Microorganisms (UFC/ml) } \\
\hline aerobic mesophils & $195.7 \pm 149.6$ & $120 \pm 276$ \\
\hline moulds & $3 \pm$ & \pm 6 \\
\hline yeasts & $102.9 \pm 32.2$ & $78 \pm 180$ \\
\hline
\end{tabular}

SD: Standard Deviation

There was a variable load of microorganisms, as shown in Table 2. One hundred per cent of samples presented a Most Probable Number (MPN) of total and fecal coliforms of 240,000 MPN/100ml. In these samples, there was no statistically significant association between the presence of aerobic mesophils, moulds and yeasts and the presence of FLA.

\section{DISCUSSION}

A number of human cases of meningitis caused by FLA $^{48}$ have been recently described and a few cases reported in Venezuela ${ }^{31015}$. However, the real incidence of this infection in this country is unknown due to a lack of experience in its diagnosis ${ }^{13}$ and only clinical cases caused by $N$. fowleri and B. mandrillaris ${ }^{31015}$ have been described.

All over the world more than 100 cases caused by Naegleria have been reported, 50 of them in USA and more than 40 cases of amoebic granulomatous encephalitis (AGE) were caused by Acanthamoeba spp and B. mandrillaris ${ }^{246}$.

The increasing number of reported cases of PAM is associated with improved identification of this amoeba due to more accurate laboratory and clinical methods and a better understanding of the evolutive cycle of the amoeba ${ }^{910}$.

In the present case, PAM was caused by contact with contaminated water, as was shown in the study of untreated water from brooks in Independencia County.

There was clinical evidence of congestive oropharyngeal mucosa, as described also by other authors ${ }^{115}$. It is known that this amoeba produces rhinitis when it reaches the nasal cavity. Patients die a short time after the onset of symptoms and only a few surviving patients have been reported ${ }^{1}$. This patient had presented symptoms for two days and died 24 hours after being admitted to hospital. Cerebral edema and cerebellar hernia were the direct cause of death ${ }^{1619}$.

Health care personnel must be aware of the possible diagnose of FLA infection when there are antecedents of swimming in thermal, stagnant or contaminated water and the patient presents with sudden symptoms of meningoencephalitis ${ }^{19}$. Few cases have been verified by means of cultures, since amoeba growth is not always achieved, even when special media are used. Etiological diagnosis is usually made post mortem, as has occurred in most cases of meningoencephalitis by Naegleria ${ }^{15} 19$.
It should be noted that the CSF must be carefully observed by direct examination, since moving amoebae can be easily identified. The use of Giemsa, Wright or Lugol stains is very important in the analysis of the CSF, in order to show the relevant structures of this protozoan.

In this study the presence of Naegleria sp was shown in water originating from the brooks of Independencia County, Anzoategui State. In a similar way, Avila et al showed trophozoites and cysts of the same genus in water from Las Cocuizas Park, Maracay City, Aragua State, Venezuela 3 .

In this study, as in others ${ }^{5}$, the isolation of Naegleria sp in brooks has been shown to occur in environmental conditions revealing high levels of water contamination by coliforms.

Using the same methods for studying water, Avila et al, showed a MPN of fecal and total coliforms higher than that established by the rules of COVENIN and their results were similar to the data reported here, except that the number of mesophils was lower ${ }^{3}$.

In this research there was no evidence of other species, like Acanthamoeba spp or Ballamuthia spp, although they have been isolated in other countries ${ }^{16}$. Another study in Venezuela showed only the presence of Naegleria $\mathrm{sp}^{3}$.

Observation of amoebae using smears and monoxenic cultures can be performed quickly and timely. The isolation efficiency for this amoeba was acceptable (44.4\%), in comparison to $23.3 \%$ that was obtained in other studies in Las Cocuizas Park ${ }^{3}$. There are other methods that could be applied in the isolation of amoebae, like filtration, centrifugation, immune-enzymatic techniques using DNA probes and indirect immunofluorescence using monoclonal antibodies ${ }^{6} 161418$. Additionally, new methods like solid phase cytometry have been developed for detecting FLA in the environment ${ }^{15}$.

Recent studies have shown more than 30 variants of $N$. fowleri by applying the methods of DNA amplified polymorphism or RAPD ${ }^{18}$. In the area described, the water temperature showed a mean of $28^{\circ} \mathrm{C}$. In some cases Naegleria has been shown to multiply in water pipelines that have been exposed to atmospheric temperatures higher than $25^{\circ} \mathrm{C}^{1}$. A high number of this amoeba was found in a channel near a lead and zinc factory during the summer, when the temperature was $31^{\circ} \mathrm{C}$ and a case of PAM in a child that swam in this location was reported 5 .

In this study, the use of smears of water or monoxenic cultures was shown to be useful for the isolation of FLA of the genus Naegleria spp. An increase in both clinical and epidemiological studies related to FLA infection is required. Moreover, health authorities should be aware of this infection in order to carry out improved sanitary control and education. FLA infections are not yet a public health problem like other parasitological diseases (malaria, trypanosomiasis or amebiasis). Nevertheless, given the fatal outcome of FLA infections, more research should be realized in these communities.

In conclusion, Naegleria $s p$ was present in untreated water from Independencia county, Anzoátegui State and this is a strong potential risk for people swimming in these brooks. 


\section{ACKNOWLEDGMENTS}

The authors are grateful to Dr. Carlos Aguilar, Dra. Julmery Cermeño and Dr. Salvador Penna for their review of the manuscript.

\section{REFERENCES}

1. Anderson K, Jamieson A. Primary amoebic meningoencephaly. Lancet 1 : 902-903,1972.

2. Ansbacher L, Benson R, Hutchison R, Rogers W. Cerebrospinal fluid centrifuge analysis in primary amebic meningoencephalitis due to Naegleria fowleri. Archives of Pathology and Laboratory Medicine 109: 668-671, 1985 .

3. Ávila J, Rodríguez G, Infantes D, Álvarez 0, Briceño M. Presencia de amebas de vida libre potencialmente patógenas en aguas del parque Las CocuizasMaracay-Edo.Aragua-Venezuela. Revista Talleres 7: 136, 2001.

4. Barnett N, Kaplan A, Hopkin R, Saubolle Rudinsky M. Primary amoebic meningoencephalitis with Naegleria fowleri. Pediatric Neurology 15: 230234, 1996

5. De Jonckheere J, Van Dijck P, Van De Voorde H. The effect of thermal pollution on the distribution of Naegleria fowleri. Journal Hygiene (Lond) 75: 7-13, 1975 .

6. Garcia, L. Diagnostic Medical Parasithology. $4^{\text {ta }}$ edition. Asm. Press. Washington. p.1092, 2001.

7. John DT. Primary amebic meningoencephalitis and the biology of Nagleria fowleri. Annual Review of Microbiology 36: 101-123, 1982.

8. Kodet R, Nohynkova E, Tichy M, Soukup J, Visvesvara G. Amebic encephalitis caused by Balamuthia mandrillaris a Czech child: description of the first case from Europe. Pathology Research and Practice 194: 2423-2429, 1998.
9. Martinez A, Guerra A, García J, Céspedes G, Gonzalez J, Visvesvara G. Granulomatous amebic encephalitis: A review and report of a spontaneous case from Venezuela. Acta Neuropathologica 87:430-434, 1994.

10. Martínez A, Visvesvara G. Laboratory diagnosis of pathogenic free-living amoebae: Naegleria, Acantamoeba, and Leptomyxid. Clinics in Laboratory Medicine 11: 861-872, 1991.

11. Normas COVENIN Venezolanas. 2409: 86. Agua. Método de membrana filtrante para análisis microbiológico. p. 1-14, 1994.

12. Normas Covenin Venezolanas. 2614. Agua Potable. Toma de Muestra. p. 1-8, 1994 .

13. Pungnard C, Catala P, Drocourt J, Legastelois S, Pernin P, Pringuez E, Lebaron P. Rapid detection and enumeration of Naegleria fowleri in surface waters by solid-phase cytometry. Applied and Environmental Microbiology 68: 3102-3107, 2002.

14. Reveller F, Varenne M, Pougnard C, Cabanes P, Pringuez E, Pourima B. An Enzyme-Linked ImmunoSorbent Assay (ELISA) for the identification of Naegleria fowleri in enviromental water samples. Journal of Eukaryotic Microbiology 50: 109-113, 2003.

15. Rodríguez R, Méndez 0, Molina 0, Luzardo G, Martinez A, Vivesvara G, Cardozo J. Infección del Sistema Nervioso Central por amebas de vida libre: Comunicación de tres nuevos casos venezolanos. Revista de Neurología 26: 1005-1008, 1998 .

16. Rohr V, Weber S, Michael R, Selenka F, Wilhelm M. Comparison of freeLiving amoebae in hot water systems of hospitals with isolate from moist sanitary areas by identifying genera and determining temperature tolerance. Applied and Environmental Microbiology 64:1822-1824, 1998.

17. Shuster F, Vivesvara G. Free-living amoeba as opportunistic and nonopportunistic pathogens of human and animals. International Journal for Parasitology 34:1001-1027, 2004.

18. Sparagano 0. Detection of Naegleria fowleri cysts in environmental samples by using a DNA probe. FEMS Microbiology Letters 112: 349-351, 1993.

19. Visvesvara G, Sehr-Green JK. Epidemiology of free-living ameba infections. Journal of Protozoology 37: 25S-33s, 1990. 